\title{
Chitosan-based foliar application modulated the yield and biochemical attributes of peach (Prunus persica L.) CV. Early Grand
}

Muhammad Sajid ${ }^{1}$, Abdul Basit ${ }^{1}$, Zafar Ullah ${ }^{1}$, Syed Tanveer Shah ${ }^{1}$, Izhar Ullah ${ }^{1}$, Heba I. Mohamed ${ }^{2 *}$ and Inayat Ullah ${ }^{1}$

\begin{abstract}
Background: Peach fruits are highly perishable leading to many pre- and post-harvest problems, which adds to the reduction in the potential yield and productivity. Chitosan is a natural polysaccharide, produced after alkaline chitin deacetylation. It is one of the most preferred biopolymers due to its biocompatibility, antioxidant, anticancer, biodegradability, antimicrobial, and non-toxic properties as well as being an economical material. A pre-harvesting experiment was carried out based on the problems of peach and the importance of chitosan.

Results: Peach trees were foliar sprayed with different concentrations of chitosan $(0,0.50,0.75$, and $1.0 \%)$ at different times (30, 50, and 70 days after full bloom) to elucidate the effect of chitosan to peach yield and fruit quality. The results showed that foliar application of chitosan (1\%) caused significant increases in fruit weight, volume, tree yield ${ }^{-1}$, fruit firmness, titratable acidity, and ascorbic acid content but caused significant decreases in total soluble solid fruit juice $\mathrm{pH}$ and disease incidence of peach fruit. Similarly, foliar application of chitosan after 50 days of full bloom increased fruit weight, volume, yield tree ${ }^{-1}$, firmness, titratable acidity, and ascorbic acid content with the number of fruit $\mathrm{kg}^{-1}$, total soluble solids, juice $\mathrm{pH}$, and disease incidence as compared to other application times.

Conclusions: It is concluded that chitosan at $1 \%$ applied after 50 days of full bloom improved most of the peach attributes studied compared to the other concentrations of chitosan at 0.50 and 0.75 , and control for the production of quality peach fruit.
\end{abstract}

Keywords: Chitosan modulates, Eco-friendly compound, Peach fruit, Perishability, Antimicrobial, Physiochemical attributes

\section{Background}

Peach (Prunus persica L.) is a member of the Rosaceae family and is considered the second most important stone fruit in Pakistan (GOP 2015). In addition to carbohydrates, organic acids, pigments, volatiles, nutrient minerals, and trace amounts of proteins and lipids, a peach fruit contains an immense diversity of biologically

\footnotetext{
* Correspondence: hebaibrahim79@gmail.com

${ }^{2}$ Faculty of Education, Department of Biological and Geological Sciences, Ain Shams University, Cairo, Egypt

Full list of author information is available at the end of the article
}

bioactive compounds such as vitamin $\mathrm{C}$, carotenoids, flavonoids, and phenols that act as antioxidants, making the peach fruit very attractive to consumers for nutritional and health issues (FAOSTAT 2016). In Pakistan, the peach cultivation area is 13.819 thousand hectares, and the total annual production is 70.75 thousand tons. The most commonly used peach cultivars in Pakistan are Early Grand, Florida King, Shireen, Shah Pasand, Golden Early, 6th A, 8th A, etc. In KP, peaches occupy $19 \%$ of the total fruit land. In Malakand Division, the average production of peach is 12.53 tons/ha including

\section{Springer Open}

() The Author(s). 2020 Open Access This article is licensed under a Creative Commons Attribution 4.0 International License, which permits use, sharing, adaptation, distribution and reproduction in any medium or format, as long as you give appropriate credit to the original author(s) and the source, provide a link to the Creative Commons licence, and indicate if changes were made. The images or other third party material in this article are included in the article's Creative Commons licence, unless indicated otherwise in a credit line to the material. If material is not included in the article's Creative Commons licence and your intended use is not permitted by statutory regulation or exceeds the permitted use, you will need to obtain permission directly from the copyright holder. To view a copy of this licence, visit http://creativecommons.org/licenses/by/4.0/. 
Swat (4.2 thousand hectares) and Mardan (0.38 thousand hectares) with a production of 43.94 and 3.64 thousand tons, respectively (FAOSTAT 2016). Peach fruit is considered to be one of the most perishable in nature and is susceptible to many diseases (scab, anthracnose, bacterial spot, brown rot, etc.), insects, and pests, and at various stages of growth (Hartman 2007). Peach fruit is also susceptible to pre-harvest contamination and physical damage, leading to problems such as surface discoloration etc. (Crisosto et al. 2000). Due to its perishable nature, it does not maintain its quality after harvest for an extended period. In order to increase or enhance the shelf life of peach to meet consumer's demand, a number of techniques such as fumigation and pre-harvest spraying of nutrients are used to overcome the postharvest losses of fruit commodities (Neo and Saikia 2010). During marketing or shipping, peach fruits suffer from high susceptibility to flesh softening that makes it more sensitive for pathogen attack and deterioration leading to a shorter handling period and limited marketability. Therefore, post-harvest practices for maintaining fruit characters of improved marketing capability and extended shelf life are seriously considered. It would be achieved by reducing the quality losses due to the physiological and biochemical changes that fruits undergo after harvesting. Physiological weight loss of about $20-30 \%$ (Ullah et al. 2018) is determined by both water loss, due to transpiration of the living fruit tissues, and by dry matter loss due to respiration. Also, a wide range of post-harvest fruit losses is caused by several post-harvest diseases. In this regard, efforts are being made to find effective and safe techniques to control fruit post-harvest diseases, reduce quality losses, and increase the production and quality of fruits, as an alternative to the use of synthetic fungicides (Mohamed and Akladious 2017; Mohamed et al. 2018).

Jasmonates, essential oils, benzothiadiazole, and trichoderma are examples of natural compounds that help to minimize plant infections (Aly et al. 2012, 2013, 2017; Abd El-Rahman and Mohamed 2014; Ashry et al. 2018). In addition, the use of natural compounds such as chitosan is one of the most fascinating and satisfactory methods.

Chitosan is a naturally occurring compound that is commercially produced from seafood shells. It has been used to induce the defense system for both pre- and post-harvest fruits and vegetables against fungi, bacteria, viruses, and other abiotic stresses. In addition to that, chitosan effectively improves the physiological properties of plants and also enhances the shelf life of post-harvest products. In addition, the treatment of chitosan regulates several genes in plants, particularly the activation of plant defense signaling pathways (Sofy et al. 2020a, 2020b). Chitosan is a less toxic and economical compound that is biodegradable and environmentally friendly with a variety of applications in agriculture (Basit et al. 2020) and is edible and safe for both animals and plants. Chitosan bears a negative charge due to the amino and hydroxyl groups responsible for its distinctive physiological, biological, and coating properties on the surface of fruit and vegetables which are positively charged due to the presence of organic acids. The use of chitosan helps to induce drought resistance and improves the efficiency of water use (Hassnain et al. 2020). Due to its biological activities and mode of action, it is considered as an antimicrobial compound and can be used against microorganisms and as an inducer of the plant defense mechanisms (Sofy et al. 2020a, 2020b). It also helps stimulate plant immune systems, plant growth, and plant protection against various insects, pests, diseases, and microorganisms (Sofy et al. 2020a, 2020b). chitosan effects on fruit physiology and agronomic traits have been highly studied using different concentrations of chitosan in a variety of fruits. In line with this, foliar spraying of $5 \mathrm{~mL} \mathrm{~L}^{-1}$ chitosan over mango trees improved the number of fruit tree ${ }^{-1}$, the weight, the size of the fruit, and the vegetative growth (Zagzog et al. 2017). However, information regarding the use and effect of exogenous application of chitosan at different times on the quality production of peach fruit has not yet been systematically documented. Therefore, the present is planned to study the effects of chitosan and its time of application alone and in combination on the yield-related characteristics and biochemical attributes of peach fruit.

\section{Methods}

\section{Experimental site and plant material}

This research was conducted at Horticulture Research Farm, Agriculture Peshawar University in 2018 (longitude 710 o50, latitude 340 o01), Peshawar, Pakistan. The research farm is located at $34.01^{\circ} \mathrm{N}$ latitude, $71.35^{\circ} \mathrm{E}$ longitude at an altitude of $350 \mathrm{~m}$ above sea level in Peshawar valley with a sub-tropical climate (Ahmad et al. 2019). Peshawar is located approximately $1600 \mathrm{~km}$ north of the Indian Ocean. The research farm is irrigated by the Warsak canal from river Kabul (Alam et al. 2020). Both the summer and winter weathers are extreme (Basit et al. 2019), characterized by severe winter and hot prolonged summer where the average minimum temperature during winter is $50{ }^{\circ} \mathrm{C}$ while during summer, the average maximum temperature reaches up to $45{ }^{\circ} \mathrm{C}$. The wettest month (with the highest rainfall) is March $(78 \mathrm{~mm})$ and driest month (with the lowest rainfall) is June $(7 \mathrm{~mm})$ approximately. Peach orchard already established at Horticultural Research Farm, Peshawar University of Agriculture, was used for the experiment. Peach cv. Early Grand of age approximately 10 years were selected to be pruned in the months of 
November to December on a regular basis to avoid alternating bearings. Peach trees were planted in a square system with a plant-to-plant and row-to-row distance of $6 \mathrm{~m}$. Cultural practices such as weeding, irrigation, fertilizer application, and pruning have been carried out on a regular basis. Uniform-sized disease-free trees were selected for the experiment.

\section{Experimental design and treatment combinations}

The experiment was carried out using randomized complete block design (RCBD) with split plot arrangement having two factors which were replicated three times. Peach cv. Early Grand was sprayed with different concentrations of chitosan $(0,0.50,0.75$, and $1.0 \%)$ at three different timings $(30,50$, and 70 days after full bloom). The number of treatments per replication is 12 , while the total number of treatments is 36 . Three trees were assigned for each experimental treatment, so the total number of trees used for this experiment was 108. Growth conditions are the same. The concentration of chitosan is selected according to the previous studies (Hong et al. 2016). Peach fruit cv Early Grand was harvested at the edible maturity stage with golden yellow color. The fruits had been cleaned and washed with distilled water. Fruit sorting was done by removing the disease-affected, injured, and damaged fruit. The remaining fruit was selected for physiochemical analysis.

\section{Procedure for preparation and foliar spray of chitosan solution}

For the preparation of different concentrations (0.5, 0.75 , and $1.0 \%$ ) of chitosan solutions, $0.5,0.75$, and $1.0 \mathrm{~g}$ of chitosan (C18H35N3O13) were then dissolved in 100$\mathrm{mL}$ distilled water. Since chitosan cannot be dissolved easily in water, a few drops of diluted acids in the form of citric acid have been added to the solution for the uniform dissolution of chitosan. Each solution was stirred for $1 \mathrm{~h}$ on a magnetic stirrer to completely dissolve chitosan particles in the water (Sandeep et al. 2013). Each peach required $4 \mathrm{~L}$ of water, so the chitosan solution was prepared in a 4 -L solution in each treatment. Three trees are sprayed with chitosan.

\section{Yield-contributing traits of peach fruit}

Three fruits were selected randomly from each treatment to determine the weight of the fruit $(\mathrm{g})$. For each treatment volume, the water displacement method (WDM) was used. A simple graduated cylinder of $1 \mathrm{~L}$ was used containing water. Randomly selected fruits were placed into it, and the difference between the initial and final readings was noted. The final harvested fruits (yield tree ${ }^{-1}$ ) of all randomly selected trees for each treatment in each replication were measured in kilograms $(\mathrm{kg})$ with the aid of balancing, and then their average was calculated. Percent incidence of disease was estimated using the following formula:

$$
\text { Disease incidence }(\%)=\frac{\text { No.of infected fruits per treatment }}{\text { Total no.of fruits per treatment }} \times 100
$$

\section{Physiological attributes of peach}

The firmness of peach fruit was measured with the penetrometer (Model-Wagner FT-327, fruit firmness analyzer) with a capacity of $28 \mathrm{lb}$ (Basit et al. 2020). For this purpose, the instrument's probe was inserted into the pulp of peach fruit, and reading was noted. The firmness of the three fruits was determined from each treatment, and then their average was calculated. The refractometer was used to analyze the total soluble solids (0Brix) in peach fruit. The total soluble solids and titrable acidity were calculated using the AOAC (2000). For this purpose, few drops of juice were placed on the prism and slide, and the reading was then recorded. For titratable acidity, the juice was extracted from the randomly selected peach fruit and used to extent titratable acidity and then was expressed in percent. Burette reading was noted, and the percentage of titrable acidity was observed with the help of the given formula.

$$
\text { Titratable Acidity }(\%)=\frac{N \times T \times F \times 100}{D \times S} \times 100
$$

where $N$ is the normality of $\mathrm{NaOH}(0.1), T$ is the titration reading, $F$ is the constant acid factor (0.067) (citric acid), $D$ is the volume ( $\mathrm{mL}$ ) of the sample taken for dilution $(10 \mathrm{~mL})$, and $S$ is the volume $(\mathrm{mL})$ of the diluted sample taken for titration $(10 \mathrm{~mL})$.

The "dye method" was used (Ranganna 1977) for the purpose of ascorbic acid (mg $100 \mathrm{~g}^{-1}$ ) content. Reading for ascorbic acid content was taken by using the following described formula.

$$
\text { Ascorbic Acid contents }=\frac{T \times F \times 100}{D \times S} \times 100
$$

whereas $T$ is the volume $(\mathrm{mL})$ of the dye solution used from the burette, $F$ is the dye factor $(0.11), D$ is the fruit juice (g) taken for dilution $(10 \mathrm{~mL})$, and $S$ is the volume $(\mathrm{mL})$ of the diluted sample taken for titration $(10 \mathrm{~mL})$.

The $\mathrm{pH}$ of the fruit was determined by using an electronic $\mathrm{pH}$-meter by using the procedure as suggested by Sajid et al. (2019). For this purpose, the instrument probe ( $\mathrm{pH}$-meter) was inserted into the extracted juice from peach, and $\mathrm{pH}$ value was noted after the instrument was standardized

\section{Results}

Yield contributing traits of peach fruit

The effect of the concentration of chitosan and its time of application on the physical attribute of peach fruit 
was found to be significant $(p \leq 0.05)$ while their interaction was found non-significant (Table 1 and Fig. 1). Comparing the mean concentration of chitosan, it was observed that treatment with $1.0 \%$ of chitosan caused a significant increase in fruit weight $(91.11 \mathrm{~g})$, fruit volume $(101.33 \mathrm{~cm} 3)$, and fruit yield $(92.89 \mathrm{~kg})$ tree $^{-1}$, but caused a significant decrease in the number of fruit (11.78) $\mathrm{kg}^{-1}$ and disease incidence $(2.11 \%)$ of peach compared to control plants $(0 \%$ chitosan) which showed the minimum fruit weight $(61.56 \mathrm{~g})$, volume $(75.11 \mathrm{~cm} 3)$, and yield $(68.78 \mathrm{~kg})$ tree $^{-1}$ and maximum number of fruit (17.78) $\mathrm{kg}^{-1}$ and disease incidence (10.33\%) of peach (Fig. 3a). Regarding the time of application, peach plants treated with chitosan after 50 days of full bloom achieved the highest fruit weight $(81.25 \mathrm{~g})$, fruit volume $(90.33$ $\mathrm{cm} 3$ ), fruit yield $(86.58 \mathrm{~kg})$ tree $^{-1}$, and minimum fruit (14.08) $\mathrm{kg}^{-1}$ and disease incidence (4.82\%) of peach. On the other side, the lowest value of fruit volume (87.17 $\mathrm{cm} 3)$ and yield $(77.25 \mathrm{~kg})$ tree $^{-1}$ of peach was recorded in fruits sprayed with chitosan after 70 days of full bloom. The maximum number of fruits (90.33) and disease incidence $(5.52 \%)$ was observed in plants sprayed with chitosan after 50 days of full bloom (Fig. 4a).

\section{Biochemical attributes of peach fruit}

It is clear from Table 1 and Fig. 2 that the different concentrations of chitosan and its time of application significantly affected the biochemical attributes of peach fruit, whereas their interaction was found to be insignificant. The chitosan concentration ranged from 0 to $1.0 \%$, fruit firmness ranged from 1.07 to $2.50 \mathrm{~kg} / \mathrm{cm}^{2}$, total soluble solid (9.98 to 7.33 0Brix), fruit juice $\mathrm{pH}$ (5.40 to 4.69), titrable acidity ( 0.19 to $0.64 \%)$, ascorbic acid ( 0.28 to $0.71 \mathrm{mg} 100 \mathrm{~g}^{-1}$ ) (Fig. 3b). Comparing the means of application time of chitosan, treatment with chitosan after 50 days of full bloom caused a significant increase in the fruit firmness $\left(1.93 \mathrm{~kg} / \mathrm{cm}^{2}\right)$, total soluble solids (8.97 0Brix), and titrated acidity $(0.45 \%)$ and a significant decrease in ascorbic acid contents $\left(0.48 \mathrm{mg} 100 \mathrm{~g}^{-1}\right)$ of peach, whereas plants treated with chitosan after 70 days of full bloom showed a significant decrease in fruit firmness $\left(1.74 \mathrm{~kg} / \mathrm{cm}^{2}\right)$, titrated acidity $(0.41 \%)$, and ascorbic acid contents $\left(0.48 \mathrm{mg} 100 \mathrm{~g}^{-1}\right)$. In addition, the minimum total soluble solids (8.70 0Brix) and fruit juice $\mathrm{pH}$ (4.97) of peach were recorded in fruit plants treated with chitosan after 50 days of full bloom (Fig. 4b).

\section{Discussion}

The improvement in fruit weight may be due to the increase in the metabolic activity of some important enzymes (protease, nitrate reductase, and glutamine synthetase) and increased photosynthesis which enhanced plant growth and development (Mondal et al. 2012). Besides this, chitosan induces the synthesis of plant hormones such as gibberellins, which are responsible for the development of ovaries into fruits. It also increases growth through some signaling pathways related to the biosynthesis of auxin (El-Bassiony et al. 2014). In addition, it has also been accredited to intensification in the availability and uptake of water and essential nutrients by adjusting osmotic pressure cells and reducing the accumulation of harmful free radicals by enhancing antioxidants and enzymatic activities (Guan et al. 2009; El-Beltagi et al. 2020). As a result, the use of chitosan increases photosynthetic pigment by increasing photosynthesis (El-Tantawy 2009) and the common plant growth compared to control plants (Abu-Muriefah 2013). These results are in accordance with those found by El-Miniawy et al. (2013) on cucumber that time of application of chitosan significantly affected the plant growth parameters. Applying chitosan after 50 days of full fruit shows a maximum increase in fruit weight, as stone fruit is currently undergoing cell elongation. Applying chitosan at the cell elongation stage of stone fruit enhances essential enzyme activity and provides more nutrients for the growth and development of fruit. Mahmood et al. (2017) reported that the foliar application of $0.5 \%$ chitosan (at 7-day intervals, starting from 2 weeks

Table 1 Mean square value of various attributes of peach influenced by chitosan concentration and its time of application

\begin{tabular}{|c|c|c|c|c|c|c|c|c|c|c|c|}
\hline \multirow[t]{2}{*}{ SOV } & \multirow[t]{2}{*}{ Df } & \multirow[t]{2}{*}{ SFW } & \multirow[t]{2}{*}{ FrV } & \multirow[t]{2}{*}{ NOFPP } & \multirow[t]{2}{*}{ FYPT } & \multicolumn{2}{|c|}{ Mean square (MS) } & \multirow[t]{2}{*}{ TSS } & \multirow[t]{2}{*}{ TA } & \multirow[t]{2}{*}{$\mathrm{AA}$} & \multirow[t]{2}{*}{ FJpH } \\
\hline & & & & & & $\mathrm{DI}$ & FrF & & & & \\
\hline Reps & 2 & $4.75^{\mathrm{ns}}$ & $0.583^{\text {ns }}$ & $0.361^{\text {ns }}$ & $29.361^{\mathrm{ns}}$ & $1.478^{\mathrm{ns}}$ & $0.01^{\mathrm{ns}}$ & $0.005^{\text {ns }}$ & $0^{\text {ns }}$ & $0.008^{\mathrm{ns}}$ & $0.004^{\text {ns }}$ \\
\hline Time (S) & 2 & $24.333^{* *}$ & $30.083^{* *}$ & $4.111^{*}$ & $308.028^{*}$ & $1.712^{*}$ & $0.114^{* *}$ & $0.214^{* *}$ & $0.003^{*}$ & $0.031^{*}$ & $0.021^{*}$ \\
\hline Error-I & 4 & 0.958 & 1.292 & 0.361 & 25.361 & 0.214 & 0.006 & 0.008 & 0 & 0.004 & 0.003 \\
\hline Chitosan (C) & 3 & $1584.18^{* * *}$ & $1188.1^{* * *}$ & $63.88^{* * *}$ & $872.519^{* * *}$ & $120.439^{* * *}$ & $3.626^{* * *}$ & $12.671^{* * *}$ & $0.366^{* * *}$ & $0.293^{* * *}$ & $0.846^{* * *}$ \\
\hline $\mathrm{S} \times \mathrm{C}$ & 6 & $7.148^{\text {ns }}$ & $2.824^{\mathrm{ns}}$ & $0.407^{\mathrm{ns}}$ & $157.324^{\mathrm{ns}}$ & $0.691^{\mathrm{ns}}$ & $0.001^{\mathrm{ns}}$ & $0.016^{\mathrm{ns}}$ & $0^{\text {ns }}$ & $0.001^{\mathrm{ns}}$ & $0.006^{\mathrm{ns}}$ \\
\hline Error-II & 18 & 4.074 & 1.611 & 0.287 & 75.694 & 0.783 & 0.016 & 0.018 & 0.001 & 0.003 & 0.002 \\
\hline Total & 35 & & & & & & & & & & \\
\hline
\end{tabular}

ns non-significant, SFW single fruit weight, FrV fruit volume, NOFPP no. of fruit per plant, FYPT fruit yield per tree, DI disease incidence, FrF fruit firmness, TSS total soluble solid, TA titratable acidity, $A A$ ascorbic acid, $F r J p H$ Fruit juice $\mathrm{pH}$

${ }^{* * *} p \leq 0.001 ;{ }^{* *} p \leq 0.01 ;{ }^{*} p \leq 0.05$ 


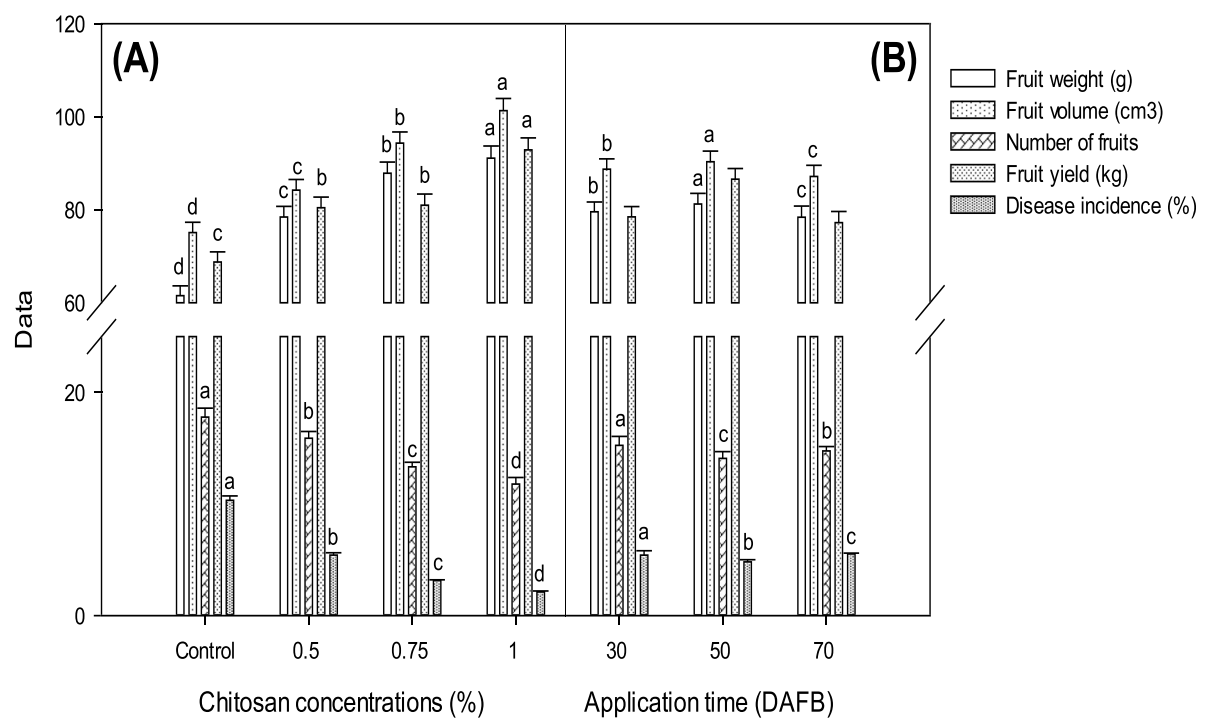

Fig. 1 Fruit weight, fruit volume, number of fruits, fruit yield $\mathrm{kg}^{-1}$, and disease incidence of peach as influenced by different chitosan concentrations and application time. The vertical bars represent standard error. Different letters next to the mean values in each bar indicate a significant difference (LSD $p \leq 0.05)$

after transplantation) increases the fruit weight, the diameter, and the yield of bell pepper (Capsicum annum L.). Usually, fruit volume and weight are directly correlated with each other where an increase in volume may result in an increase in weight. The increase in fruit volume may be due to the high content of starch and plant hormones, especially cytokines, which play a vital role in enhancing cell division and expansion, ultimately leading to increased volume (Uthairatanakij et al. 2007). Chitosan may induce gibberellin in the ovary of the carpel, which plays a key role in the cell elongation and therefore causes an increase in size and volume (Mondal et al. 2012). It may also be attributed to an increase in the availability and uptake of water and important nutrients from the adjusting cells and xylem tissues due to osmotic pressure. This uptake of water causes turgidity of cells and dropping the accumulation of harmful free radicals by increasing antioxidants and enzyme activities (Guan et al. 2009). Applying chitosan after 50 days of full bloom showed a maximum increase in fruit weight and volume because at this time, stone fruit undergoes through the cell elongation stage. During this stage, cells

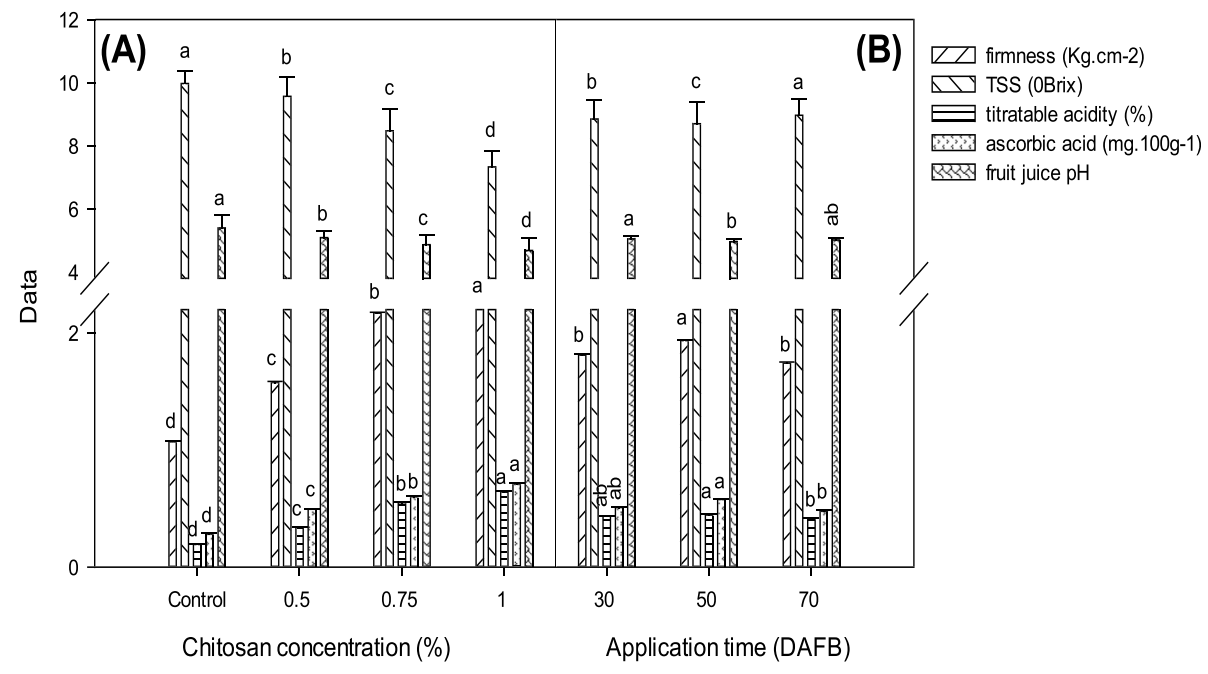

Fig. 2 Fruit firmness, total soluble solid, fruit juice $\mathrm{pH}$, titratable acidity, and ascorbic acid of peach as influenced by different chitosan concentrations and application time. The vertical bars represent standard error. Different letters next to the mean values in each bar indicate a significant difference (LSD $p \leq 0.05)$ 


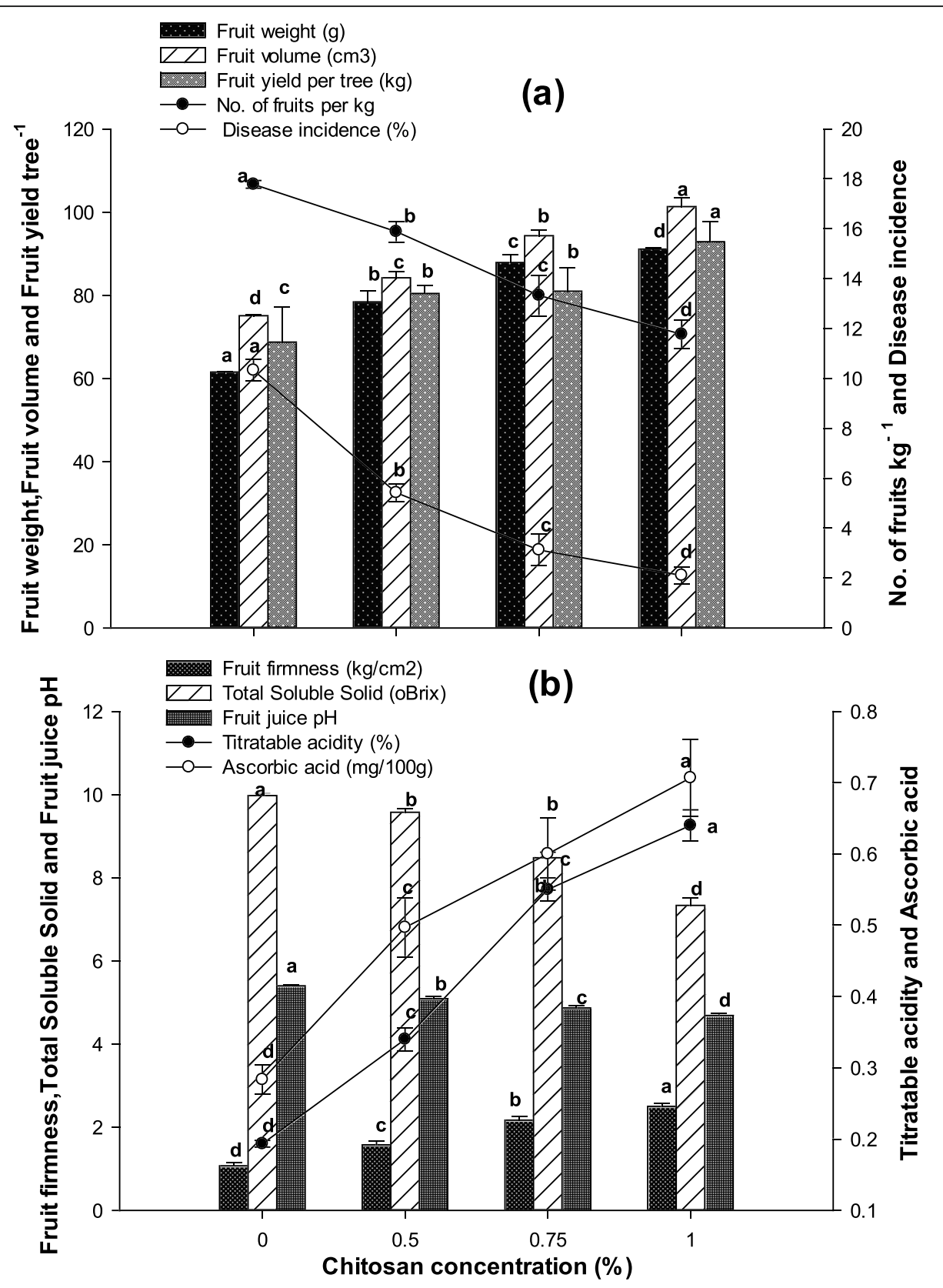

Fig. 3 Various attributes of peach as influenced by different chitosan concentrations. The vertical bars represent standard error. Different letters next to the mean values in each bar indicate a significant difference (LSD $p \leq 0.05$ )

absorb water from adjacent cells or xylem, which can cause turgidity of the cells and elongation of the fruit cells, activation of some essential enzymes and supply of more nutrients for the growth and development of fruit. Fruit weight and fruit volume are directly related to each other but show inverse relation with that of the number of fruits $\mathrm{kg}^{-1}$. Increased fruit weight causes a decrease in the number of fruits $\mathrm{kg}^{-1}$ (Gornik et al. 2008) and therefore inversely causes a decrease in the number of fruits $\mathrm{kg}^{-1}$. In case of control, the fruit weight and volume were smaller, which is why the number of fruit $\mathrm{kg}^{-1}$ was high. The foliar application of chitosan may cause an increase in the number of fruit plant ${ }^{-1}$, which ultimately leads to an increase in yield and productivity. This increase of yield in treated plants compared to untreated plants is due to the increased plant height, fruit-bearing nodes, chlorophyll contents, reduced disease incidence (Bautista et al. 2006), etc. Foliar spray of chitosan at early growth stages increases plant growth and development therefore increases seed yield in rice and soybean 


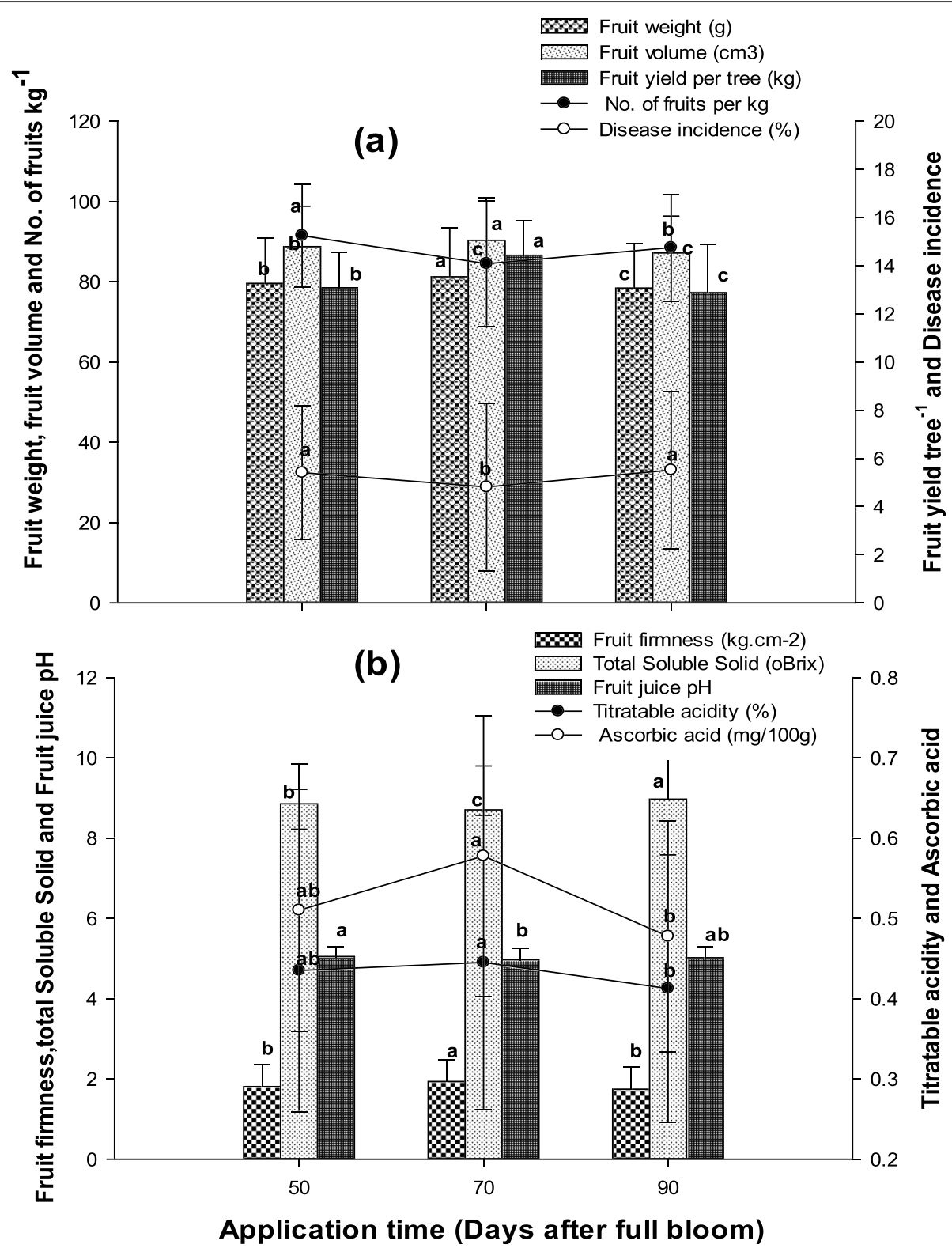

Fig. 4 Various attributes of peach as influenced by the application time of chitosan. The vertical bars represent standard error. Different letters next to the mean values in each bar indicate a significant difference (LSD $p \leq 0.05)$

(Islam et al. 2016). Pre- and post-harvest foliar application of chitosan may increase fruit yield and productivity in both in vivo and in vitro growing plants. The significant effect of chitosan on yield and its components may be due to the simulative effect of chitosan on physiological processes and enhanced transference of nitrogen in the functional leaves that improve vegetative growth and development (Gornik et al. 2008). Massimo and Cerana (2018) reported that two applications of chitosan $(250-500 \mathrm{ppm})$ at 7 -day intervals, from pre-flowering to post-flowering stage, have resulted in 56\% higher yields of fruit in strawberry cultivated plants compared to control plants. Chitosan is a natural polycation compound that reduces fungal spoilage and decay of fruit by its direct antifungal activity and by inducing host resistance to pathogens Liu et al. (2007). In the earlier comparable experiments, the application of chitosan coatings has shown benefits from reduced decay in peach, strawberry, and litchi (Chailoo and Asghari 2011; Sun et al. 2010). Chitosan induces chitinase enzymes that accelerated the hydrolysis of chitin, which is an important component of fungi cell walls, thus avoiding the growth of fungi on the fruit (Han et al. 2004). The application of chitosan stimulates the formation of structural defense 
barriers as it induces cellulose synthesis, thickening of host cell walls, formation of papillae, and plugging of some intercellular spaces with fiber material, probably impregnated with phenolic-like antifungal compounds (Sofy et al. 2020a).

Firmness is one of the most important characteristics that consumers are most interested in, and therefore, economically important in overall products is very high. Pre-harvest foliar application of chitosan may cause maintenance of fruit firmness because of the formation of a chitosan film on the fruit surface. Chitosan film acts as an oxygen barrier that slows down the metabolic activity and oxidative breakdown of glucose that leads to the ripening process (Reddy 2000). Reduction in cell wall degradation is due to chitosan coating, which in turn maintains cell turgidity and protects the structure of the cell wall. Fruit softening may be caused either by the hydrolysis of starch or by the breakdown of insoluble proto-pectins into soluble pectin or by increased membrane penetration due to cellular breakdown (Brummell and Harpster 2001). In the ripening process, the loss of pectic substances in the middle lamellae of the cell wall is the key step leading to the loss of cell integrity or firmness (Mercado et al. 2011). Higher fruit firmness during the period of the storage period of peach fruit due to pre-harvest chitosan treatments is correlated with those discovered in previous experimental studies on peach fruit (Li and Yu 2000). The total soluble solid content of a fruit is considered to be one of the main qualitative features associated with other qualitative characteristics such as firmness, composition, $\mathrm{pH}$, texture, and taste of many fruits (Peck et al. 2006; Weibel et al. 2004). Increased percentages of total soluble solids throughout the storage period are likely due to the increased enzymatic activities which are responsible for the hydrolysis conversion of starch and insoluble sugars into soluble sugars. This conversion may result in the degeneration in the amount of carbohydrates, pectin, and partial hydrolysis of protein and decomposition of glycosides into subunits during respiration (Aranzana et al. 2011). Reduction of total soluble solids with the concentration of negatively charged polysaccharide to congeal adjourned solids increases the bonding capacity of chitosan which makes the bond with sugar having positive charge (Al-Manhel and Niamah 2012). In chitosan-coated mangoes and bananas (Kittur et al. 2001), lower total soluble solid (TSS) was found as compared to control fruits while higher values were noted for treated peaches (Srinivasa et al. 2002). The TSS of chitosan-treated apricots and papayas was the same compared to the untreated fruits. The increase in the respiration rate of untreated fruits compared to treated fruits is due to the production of ethylene, which increases the consumption of organic acids and ultimately reduces the acidity of titrable fruits (Ghasemnezhad et al. 2010). Increased acidity of chitosan-coated fruits may also be due to a decrease in metabolic alteration of organic acids into $\mathrm{CO}_{2}$ and $\mathrm{H}_{2} \mathrm{O}$. This metabolic conversion may result in a reduction in the respiration rate, therefore maintaining a higher concentration of organic acids. This statement is consistent with the findings of Ali et al. (2011) who reported that titratable acidity of chitosan-coated papaya and apricot increased with time than uncoated fruits kept under cold storage. Faster reductions in titratable acidity may lead to a faster senescence (Hong et al. 2016). The results reported in this study are in agreement with those found by Elham et al. (2013) on peach and Goutam et al. (2010) on guava. Gayed et al. (2017) reported that chitosan, combined with calcium chloride, reduced the early swelling of peach trees, maintained freshness and firmness of fruits, and decreased the weight loss percentage. In nectarine, chitosan improved the soluble solid content and also helped maintained the post-harvest firmness of the fruit (Giacalone and Chiabrando 2013). Ascorbic acid has a direct relationship to acidity while it is inverse to $\mathrm{pH}$ level. The level of ascorbic acid (vitamin C) tends to decrease as the fruit ripens due to a direct action of ascorbic acid oxidase enzyme (ascorbinase), oxidation, and subsequent change of ascorbic acid into 2,3-dicetogulonicacid (Chitarra 2005). Han et al. (2004) reported delayed degradation of vitamin $C$ in chitosan-based luffa fruits (Luffa cylindrical L.). The decrease in fruit ascorbic acid, treated with chitosan, may be due to the low oxygen permeability of the chitosan coating film around the fruit surface. Low passage of oxygen level has led to a reduction in the activity of the ascorbinase which prevents oxidation of ascorbic acid (Dang et al. 2010). Like the present experiment, a high level of ascorbic acid was found consequently to chitosan application in strawberry (Wang and Gao 2013). Post-harvest chitosan coating of mango showed a reduction in the percentage of rotten tissue, increased ascorbic acid content and shelf life, and maintained freshness (Abd-Alla and Wafaa 2010).

In addition, post-harvest mango coating with edible chitosan showed a reduction in the percentage of rotten tissue, increased ascorbic acid content, increased shelf life, and continued freshness (Abbasi et al. 2009). Fruit juice $\mathrm{pH}$ is one of the most important qualitative flavor parameters. It has an indirect relationship with titratable acidity and ascorbic acid. The increase in titratable acidity of fruits causes a decrease in $\mathrm{pH}$ of the same fruit. Biochemical conditions of the fruit are changed using chitosan, which reduces the rate of respiration and metabolic processes by creating a barrier to oxygen permittivity, a real reason for $\mathrm{pH}$ change (Shaik et al. 2017). Findings of Imran et al. (2000) also support our current results which declare that prevention of pectin 
hydrolysis and development of free acids result in a reduction in pH. In addition, Kelebek et al. (2008) reported that during the storage period, an increase in the rate of respiration caused an increase in various catabolic processes which led to the breaking down of organic acids and ultimately led to an increase of fruit $\mathrm{pH}$. Also, Einbu and Varum (2003) observed that reduction in the buffering properties of the juice showed an increase in juice $\mathrm{pH}$ and decrease in the acidity of fruit throughout the storage time. These results are consistent with those of Sun et al. (2010) which have shown that the reduction in acidity during storage causes fruit senescence. The findings of Reddy (2000) revealed that chitosan over the surface of fruit acts as a barrier for the uptake of oxygen, which slows down the metabolic activity and consequently the ripening process. Coating with edible chitosan maintained fruit firmness, surface color, juice content, and other quality attributes (El Guilli et al. 2016). Ripening and fruit senescence in peach are a major issue affecting their economic value. However, treatment with chitosan resulted in a significant increase in antioxidant enzyme activity, senescence arrest, delayed fruit ripeness, and maintenance of shape and color (Ma et al. 2013).

\section{Conclusions}

From this experiment, it is concluded that pre-harvest foliar application of chitosan at $1.0 \%$ improves fruit weight, fruit volume, yield tree ${ }^{-1}$, fruit firmness, titrable acidity, ascorbic acid content, minimum number of $\mathrm{kg}^{-1}$ seed, total soluble solids, and peach fruit $\mathrm{pH}$. In fruit plants sprayed with chitosan after 50 days of full bloom, the highest fruit weight, fruit volume, yield tree ${ }^{-1}$, fruit firmness, titrable acidity, and ascorbic acid content and the minimum number of fruit $\mathrm{kg}^{-1}$, total soluble solids, and $\mathrm{pH}$ of peach fruit were recorded in fruit plants sprayed with chitosan compared with other application time. The foliar application of chitosan at $1.0 \%$ significantly after 50 days of full bloom increased all peach yield and quality attributes and therefore recommended for Peshawar valley farmers for quality peach fruit production.

\section{Supplementary information}

Supplementary information accompanies this paper at https://doi.org/10 1186/s42269-020-00405-w.

Additional file 1.

\section{Acknowledgements}

Not applicable

\section{Authors' contributions}

Z.U. and S.T.S. conceived and designed the experiments. Z.U. and A.B. performed the experiments. Z.U., S.T.S., and I.U. analyzed the data. Z.U., I.U., and A.B. contributed materials/analysis/tools. A.B., S.T., I.U., and H.I.M. wrote the paper. H.I.M. and A.B. reviewed the manuscript. M.S. supervised the experiment. All authors read and approved the final version.

Funding

There is no funding.

Availability of data and materials

Not available

Ethics approval and consent to participate

Not applicable

Consent for publication

Not applicable

\section{Competing interests}

The authors declare that they have no competing interests.

\section{Author details}

${ }^{1}$ Department of Horticulture, The University of Agriculture, Peshawar, Pakistan. ${ }^{2}$ Faculty of Education, Department of Biological and Geological Sciences, Ain Shams University, Cairo, Egypt.

Received: 20 July 2020 Accepted: 18 August 2020

Published online: 07 September 2020

\section{References}

Abbasi NA, lqbal Z, Maqbool M, Hafiz IA (2009) Post-harvest quality of mango (Mangifera indica $\mathrm{L}$.) fruit as affected by chitosan coating. Pak J Bot 41:343357

Abd El-Rahman SS, Mohamed HI (2014) Application of benzothiadiazole and Trichoderma harzianum to control faba bean chocolate spot disease and their effect on some physiological and biochemical traits. Acta Physiol Plant 36(2):343-354

Abd-Alla M, Wafaa M (2010) New safe methods for controlling anthracnose disease of mango (Mangifera indica L.) fruit caused by Colletotrichum gloeosporioides (Penz.). J Am Sci 8:361-367

Abu-Muriefah (2013) Effect of chitosan on common bean (Phaseolus vulgaris L.) plants grown under water stress conditions. Inter Res J Agric Sci Soil Sci 6(3): 192-199

Ahmad M, Khattak MR, Jadoon SA, Rab A, Basit A, Ullah I, Khalid MA, Ullah I, Shair M (2019) Influence of zinc sulphate on flowering and seed production of flax (Linum usitatissimum L.): a medicinal flowering plant. Int J Biosci 14:464-476

Alam M, Hayat K, Ullah I, Sajid M, Ahmad M, Basit A, Ahmad I, Muhammad A, Akbar S, Hussain Z (2020) Improving okra (abelmoschus esculentus I.) growth and yield by mitigating drought through exogenous application of salicylic acid. Fres Environ Bulle 29:529-535

Ali A, Muhammad MTM, Sijam K, Sidduqui Y (2011) Effect of chitosan coatings on the physicochemical characteristics of Eksotika II papaya (Carica papaya L.) fruit during cold storage. Food Chem 124:620-626

Al-Manhel AJ, Niamah AK (2012) Effect of chitosan on apple juice quality. Inter J Agri Food Sci 2(4):153-157

Aly AA, Mansour MTM, Mohamed HI (2017) Association of increase in some biochemical components with flax resistance to powdery mildew. Gesunde Pflanz 69:47-52

Aly AA, Mansour MTM, Mohamed HI, Abd-Elsalam KA (2012) Examination of correlations between several biochemical components and powdery mildew resistance of flax cultivars. Plant Pathol J 28(2):149-155

Aly AA, Mohamed HI, Mansour MTM, Omar MR (2013) Suppression of powdery mildew on flax by foliar application of essential oils. J Phytopathol 161:376381

Aranzana MJ, Abbassi EK, Howad W, Arus P (2011) Genetic variation, population structure and linkage disequilibrium peach commercial varieties. BioMed Cen Genet 11(4):1-12

Ashry NA, Ghonaim MM, Mohamed HI, Mogazy AM (2018) Physiological and molecular genetic studies on two elicitors for improving the tolerance of six Egyptian soybean cultivars to cotton leaf worm. Plant Physiol Biochem 130: 224-234

Association of Official Analytical Chemists (AOAC) (2000) Official methods of analysis. In: Helrich K (ed) , 15th edn, Arlington, p 513 
Basit A, Hassnain M, Alam I, Ullah ST, Shah SA, Ullah I (2020) Quality indices of tomato plant as affected by water stress conditions and chitosan application. Pure Appl Biol 9(2):1364-1375

Basit A, Khan S, Sulaiman Shah S, Shah AA (2019) Morphological features of various selected tree species on the greater university campus Peshawar, Pakistan. Int J Bot Studies 4:92-97

Bautista BS, Lauzardo H, Valle VD, Lopez H, Barka EA, Molina B, Wilson CL (2006) Chitosan as a potential natural compound to control pre and postharvest diseases of horticultural commodities. Crop Prot 25(2):108-118

Brummell DA, Harpster MH (2001) Cell wall metabolism in fruit softening and quality and its manipulation in transgenic plants. Plant Mol Biol 47:311-340

Chailoo MJ, Asghari MR (2011) Hot water and chitosan treatment for the control of postharvest decay in sweet cherry (Prunus avium L.) CV. Napoleon. J Stored Products Postharv Res 2(5):135-138

Chitarra MI (2005) Post-harvest of fruit and vegetables: physiology and handling. 2.ed. UFLA, Lavras, p 785

Crisosto CH, Day KR, Johnson RS, Garner D (2000) Influence of in season foliar calcium sprays on fruit quality and surface discoloration incidence of peaches and nectarines. J Am Pomol Soc 54:118-122

Dang QF, Yan JQ, Li Y, Cheng LSC, Chen XG (2010) Chitosan acetate as an active coating material and its effect on the storing of Prunus avium L. J Food Sci 75:125-131

Einbu A, Varum KM (2003) Structure property relationship in chitosan in T. Priotr (Ed.), Chemical and functional properties of food sacchaides. p. 223.

El Guilli M, Hamza A, Clément C, Ibriz M, Ait Barka E (2016) Effectiveness of postharvest treatment with chitosan to control citrus green mold. Agriculture 6:12

El-Bassiony AM, Fawzy ZF, El-Nemr MA, Li Y (2014) Improvement of growth, yield and quality of two varieties of kohlrabi plants as affected by application of some bio stimulants. Middle East J Agric Res 13(3):491-498

El-Beltagi HS, Sofy MR, Aldaej Ml, Mohamed HI (2020) Silicon alleviates copper toxicity in flax plants by up-regulating antioxidant defense and secondary metabolites and decreasing oxidative damage. Sustainability 12:4732. https//doi.org/10.3390/ su12114732

Elham Z, El-Motty A, El-Faham SY (2013) Effect of oil coating and different wrapping materials on prolonging storage periods of Florida Prince peaches fruit. J Appl Sci Res 9(4):2927-2937

El-Miniawy SM, Ragab ME, Youssef SM, Metwally AA (2013) Effect of some agrochemicals preharvest foliar application on yield and fruit quality of "Swelling" peach trees. Alex J Agric Res 58(3):219-229

El-Tantawy EM (2009) Behaviour of tomato plants as affected by spraying with chitosan and aminofort as natural stimulator substances under application of soil organic amendments. Pak J Biol Sci 12:1 164-1173

FAOSTAT (2016) Statistical database. Food and Agriculture Organization of the United Nations, Rome http://faostat.fao.org/site/339/default.aspx

Gayed AANA, Shaarawi SAMA, Elkhishen MA, Elsherbini NRM (2017) Pre-harvest application of calcium chloride and chitosan on fruit quality and storability of 'Early Swelling' peach during cold storage. Ciência Agrotecnol 41:220-231

Ghasemnezhad M, Ali MM, Sanavi M (2010) Effect of chitosan coatings on some quality indices of apricot (Prunus armeniaca L.) during cold storage. Caspian J Env Sci 8(3): 25-33

Giacalone G, Chiabrando V (2013) Effect of preharvest and post-harvest application of chitosan coating on storage quality of nectarines. Acta Hortic 1084:675-680

Gornik K, Grzesik M, Duda BR (2008) The effect of chitosan on rooting of gravevine cuttings and on subsequent plant growth under drought and temperature stress. J Fruit Ornamental Plant Res 16:333-343

Goutam M, Dhaliwal HS, Mahajan BVC (2010) Effect of pre-harvest calcium sprays on postharvest life of winter guava (Psidium guajava L.). J Food Sci Technol 47(5):501-506

Government of Pakistan (GOP) (2015) Fruit, Vegetables and Condiments Statistics of Pakistan (2014-2015). Ministry of National Food Security \& Research Economic Wing, Islamabad

Guan YJ, Hu J, Wang XJ, Shao CX (2009) Seed priming with chitosan improves maize germination and seedling growth in relation to physiological changes under low temperature stress. J Zhejiang Univ (Sci) 10(6):427-433

Han C, Zhao Y, Leonard SW, Traber MG (2004) Edible coatings to improve storability and enhance nutritional value of fresh and frozen Strawberries (Fragaria ananassa) and Raspberries (Rubus idaeus). Postharvest Biol Technol 33:67-78

Hartman JR (2007) Peach fruit diseases. plant pathology fact sheet. UK Cooperative Extension Service, Uni.of Kentucky, College of Agri PPFS-FR-T-09.

Hassnain M, Alam I, Ahmad A, Basit I, Ullah N, Alam I, Ullah MA, Khalid B, Shair MM (2020) Efficacy of chitosan on performance of tomato (Lycopersicon esculentum L.) plant under water stress condition. Pak J Agric Res 33(1):27-41
Hong K, Xie J, Zhang L, Sun D, Gong D, Hossain MS, lqbal A (2016) Effect of shrimp chitosan coating on postharvest quality of banana fruit. Intl F Res J 23(3):277-283

Imran A, Khan R, Ayub M (2000) Effect of added sugar at various concentration on the storage stability of guava pulp. Sarhad J Agric 16:89-93

Islam MT, Mondal MMA, Rahman MS, Khanam S, Akter MB, Haque MA, Dafadar NC (2016) Effect of foliar application of chitosan on growth and yield in tomato, mung bean, maize and rice. Int I Sustain Crop Prod 11(2):7-17

Kelebek H, Canbas A, Selli S (2008) Determination of phenolic composition and antioxidant capacity of blood orange (Citrus sinensis L.) juice obtained from cvs. Food Chem 17(2):1710-1716

Kittur FS, Saroja NH, Tharanathan RN (2001) Polysaccharide based composite coating formulations for shelflife extension of fresh banana and mango. Eur Food Res Technol 213:306-311

Li H, Yu T (2000) Effect of chitosan on incidence of brown rot, quality and physiological attributes of postharvest peach fruit. J Sci Food Agric 81:269274

Liu J, Tian SP, Meng X, Xu Y (2007) Effects of chitosan on control of postharvest diseases and physiological responses of tomato fruit. Postharvest Biol Technol 44:300-306.

Ma Z, Yang L, Yan H, Kennedy JF, Meng X (2013) Chitosan and oligochitosan enhance the resistance of peach fruit to brown rot. Carbohydr Polym 94: $272-277$

Mahmood N, Abbasi NA, Hafiz IA, Ali I, Zakia S (2017) Effect of biostimulants on growth, yield and quality of bell pepper cv. Yolo wonder. Pak J Agric Sci 54: $311-317$

Massimo M, Cerana R (2018) Resent advances of chitosan application in plants. www.mdpi.com/journal/polymers. 01-10.

Mercado JA, Pliego-Alfaro F, Quesada MA (2011) Fruit shelf life and potential for its genetic improvement. In: Jenks MA, Bebeli PJ (eds) Breeding for fruit quality. Wiley, Oxford, pp 81-104

Mohamed HI, Akladious SA (2017) Changes in antioxidants potential, secondary metabolites and plant hormones induced by different fungicides treatment in cotton plants. Pestic Biochem Physiol 142:117-122

Mohamed HI, El-Beltagi HS, Aly AA, Latif HH (2018) The role of systemic and non systemic fungicides on the physiological and biochemical parameters in Gossypium hirsutum plant, implications for defense responses. Fresenius Environ Bull 27(12):8585-8593

Mondal MMA, Malek MA, Puteh AB, Ismail MR, Ashrafuzzaman M, Naher L (2012) Effect of foliar application of chitosan on growth and yield in okra. AJCS 6: 918-921

Neo GM, Saikia L (2010) Control of post-harvest pericarp browning of litchi (Litchi chinensis). J Food Sci Technol 47:100-104

Peck GM, Andrews PK, Reganold JP, Fellman JK (2006) Apple orchard productivity and fruit quality under organic, conventional and integrated management. Hortic Sci 41: 99-107

Ranganna S(1977) Manual of Analysis of Fruit and Vegetable Products. Tata McGraw-Hill, New York.

Reddy BMV (2000) Effect of pre-harvest chitosan sprays on post-harvest infection by Botrytis cinerea and quality of strawberry fruit. Postharvest Biol Technol 20:39-51

Sajid M, Basit A, Ullah I, Tareen J, Asif M, Khan S, Ali QS, Gilani SAQ, Zeb S, Nawaz MK (2019) Efficiency of calcium chloride ( $\mathrm{CaCl} 2)$ treatment on post-harvest performance of pear (Pyrus communis L.). Pure App Bio 8(2):1111-1125

Sandeep A, Sangameshwar K, Mukesh G, Kandracant R, Avinash D (2013) A brief overview on chitosan applications. Indo Am J Pharmacutical Res 13(2):1564-1574

Shaik MZ, Dakshayani L, Rani AS, Venkateswerlu G (2017) Effect of chitosan coating on the postharvest quality of banana during storage. Asian J Biotech Biores Tech 18:1-10

Sofy AR, Dawoud RA, Sofy MR, Mohamed HI, Hmed AA, El-Dougdoug NK (2020a) Improving regulation of enzymatic and non-enzymatic antioxidants and stress-related gene stimulation in Cucumber mosaic cucumovirus-infected cucumber plants treated with glycine betaine, chitosan and combination. Molecules 25:2341. https://doi.org/10.3390/molecules25102341

Sofy AR, Hmed AA, Alnaggar AM, Dawoud RA, Elshaarawy RFM, Sofy MR (2020b) Mitigating effects of bean yellow mosaic virus infection in faba bean using new carboxymethyl chitosan-titania nanobiocomposites. Int J Biol Macromol S0141-8130(20):33818-33816

Srinivasa PC, Baskaran R, Ramesh MN, Prashanth KV, Tharanathan R (2002) Storage studies of mango packed using biodegradable chitosan film. Eur. Food Res Technol 215:504-508

Sun D, Liang G, Xie J, Lei X, Mo Y (2010) Improved preserved effects of litchi by combining chitosan coating with ascorbic acid treatment during postharvest storage. African J Biot 19(2):3272-3279 
Ullah A, Khan D, Zheng S (2018) Forecasting of peach area and production wise econometric analysis. J An Plant Sci 28(4):1121-1127

Uthairatanakij A, Jaime A, Silva T, Obsuwan K (2007) Chitosan for improving orchid production and quality. Orchid Science and Biotechnology. Global Science Books.

Wang SY, Gao H (2013) Effect of chitosan based edible coating on antioxidants, antioxidant enzyme system, and postharvest fruit quality of strawberries (Fragaria $\times$ ananassa Duch.). LWT-Food Sci Technol 52:71-79

Weibel F, Widmer F, Husistein A (2004) Comparison of production systems: integrated and organic apple production. Part III: Inner quality, composition and sensory. Obstund Weibau 140:10-13

Zagzog OA, Gad MM, Hafez NK (2017) Effect of nano-chitosan on vegetative growth, fruiting and resistance of malformation of mango. Trends Hortic Res 6:673-681

\section{Publisher's Note}

Springer Nature remains neutral with regard to jurisdictional claims in published maps and institutional affiliations.

\section{Submit your manuscript to a SpringerOpen ${ }^{\circ}$ journal and benefit from:}

- Convenient online submission

- Rigorous peer review

- Open access: articles freely available online

High visibility within the field

- Retaining the copyright to your article

Submit your next manuscript at $\boldsymbol{\nabla}$ springeropen.com 